\title{
Selected Bibliography of
}

Talc in the United States

3y CELINE W. MERRILL

CONTRIBUTIONS TO ECONOMIC GEOLOGY

G E O L O G I C A L S U R V E Y B U L L E T I N $1182-\mathrm{C}$

General and specialized references

hrough December 1962

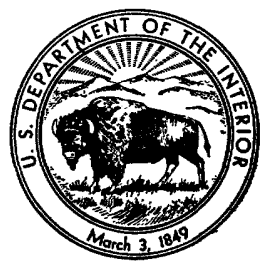


UNITED STATES DEPARTMENT OF THE INTERIOR

STEWART L. UDALL, Secretary

\section{GEOLOGICAL SURVEY}

Thomas B. Nolan, Director 


\section{CONTENTS}

Index 



\section{CONTRIBUTIONS TO ECONOMIC GEOIOGY}

\section{SELECTED BIBLIOGRAPHY OF TALG IN THE UNITED STATES}

\section{By Ceunne W. Merrifl}

\section{INTRODUCTION}

The following bibliography presents a list of both general and specialized references on talc in the United States that are available in either the library of the U.S. Geological Survey or of the Department of the Interior in Washington, D.C. A few foreign articles of general interest are also included. This bibliography is not exhaustive, but it is an attempt to provide the basis for research on the mineralogy, geology, and industrial uses of talc. The entries are arranged alphabetically by author and are indexed by subject.

The term "talc" is used in a mineralogical sense as a mineral name and in an industrial sense as a general term for a wide variety of rocks having a broad range of industrial uses. In the mineralogical sense, talc is a hydrous magnesium silicate having the general structural formula $\mathrm{Mg}_{6}\left[\mathrm{Si}_{8} \mathrm{O}_{20}\right] \mathrm{OH}_{4}$; in terms of the oxides, the formula is commonly written as $3 \mathrm{MgO} \cdot 4 \mathrm{SiO}_{2} \cdot \mathrm{H}_{2} \mathrm{O}$. By the industrial definition, the name "talc" is applied to rocks ranging in composition from those composed mainly of talc through those containing tremolite, serpentine, magnesite, and other essential minerals in addition to talc to those relatively uncommon rocks composed mostly of tremolite or serpentine. Where uncertain from the context, the intended usage will be made clear by such phrases as "the mineral talc," "talc rock," and "industrial talc."

Talc is a white, pale-green, or gray-white mineral having a pearly luster and greasy feel. It is extremely soft ( 1 on the Mohs scale), has a perfect basal cleavage, and has a specific gravity of 2.75-2.83. Most industrial tales can be distinguished by their softness and slippery feel, but the more impure varieties vary widely in hardness and texture. 
In both industrial and geologic usage, varieties of talc rocks are known by specific names, and often the industrial and the geologic terms differ in usage; furthermore, neither usage is entirely consistent. "Steatite," as a geologic term, denotes a rock composed chiefly of talc, whereas, when used in industry, it depicts a talc rock of high purity, suitable for the manufacture of electronic insulators, but for which the specifications vary for different uses and among different manufacturers. "Soapstone" is a massive variety of talcose rock suitable for the manufacture of sawed and shaped slabs. It varies widely in mineral composition, from steatite (in the geologic sense of the term) to talcose rocks containing abundant magnesite, serpentine, amphibole, pyroxene, chlorite, and mica. "Grinding talc" is a term applied to all varieties of talc suitable for grinding into powdered form. Other commonly used terms include "grit," a talc-magnesite rock; "fibrous talc," a variety of industrial talc having abundant fibrous or acicular minerals such as tremolite; and "lava talc" and "block talc," both industrial types of massive steatite.

Most commercial talc deposits are associated with ultramafic igneous rocks or dolomitic marbles. The deposits are worldwide in distribution and range from Precambrian to Tertiary in age. Both types of deposits vary in size, form, and geologic relations. Minable deposits of pure talc rock are rare and are generally small or constitute only a small proportion of larger deposits of talc-magnesite rock, talctremolite-sepentine rock, and other talcose rocks.

The properties requisite for particular talcs vary greatly and depend upon the manufacturing process and intended use. The more critical properties include the particle size and shape, the chemical composition of the mineral talc, and the identity and proportion of contaminant minerals. Particle shape is of particular importance in industrial steatites and in other tales for some industrial uses. The chemical composition of the mineral talc is of importance only in industrial steatite and in talcs for a few other ceramic uses. Though oxides, sulfates, sulfides, and many other minerals restrict the use of commercial talcs, the presence of some silicates is desirable for certain uses. For example, fabricators often require a small percentage of $\mathrm{CaO}$ in steatite, and tremolitic talc is in demand for some paints because of its white color and low oil-absorption property.

There are few substitutes for talc, and, because of its abundance, there is little demand for them. Pyrophyllite, a hydrous aluminum silicate, has properties very similar to those of talc and competes with talc for some uses.

Of the total talc consumed in the United States in 1960, more than 35 percent was used in ceramics, for which talc is especially suitable. Almost 19 percent was used in the paint industry, as 
an extender and a pigment in certain paints. More than 29 percent was used in roofing, insecticides, rubber, paper, and asphalt, both as a filler and a dusting agent. The rest went into many diverse products such as talc crayons, foundry facings, plaster products, polishing agents, textiles, tile, cements, toilet preparations, and miscellaneous other products.

The purer and whiter grinding grades of talc are used principally for steatite (in the fabrication of electronic insulators), pharmaceuticals, cosmetics, paper manufacture, and ceramics. Lower grades of talc are suitable for most other uses.

The United States leads in world production of talc and in recent years has produced about 25 percent of the world total. New York, California, Texas, Georgia, Montana, Vermont, Virginia, and Maryland lead in production; other producing States include North Carolina, Nevada, Alabama, Arkansas, and Washington. Most of Virginia's production is soapstone; she is the leading producer in the United States. Much of the "talc, soapstone, and pyrophyllite" recorded for North Carolina and California is pyrophyllite, in which these two States lead. Montana and California have been principal producers of steatite in recent years; these two States, plus North Carolina and Nevada, are the chief domestic sources of cosmetic talc. Texas has recently become a principal sourse of ceramic talc for tileware. Much of the best cosmetic talc and the highest grade steatite has long been imported from Italy and India.

Most of the talc exploited in New York, California, Montana, North Carolina, and Nevada is associated with metamorphosed carbonate rocks; that in Vermont, Virginia, Maryland, and Washington is associated chiefly or entirely with ultramafic igneous rocks, and large deposits of such talc also occur in California and other States. The deposits of Texas, Georgia, Alabama, and Arkansas include both types of associations or are of unknown or doubtful origin.

The following table shows a comparison between the United States and world annual total of talc, soapstone, and pyrophyllite production for the period 1949-60. The data are from the U.S. Bureau of Mines.

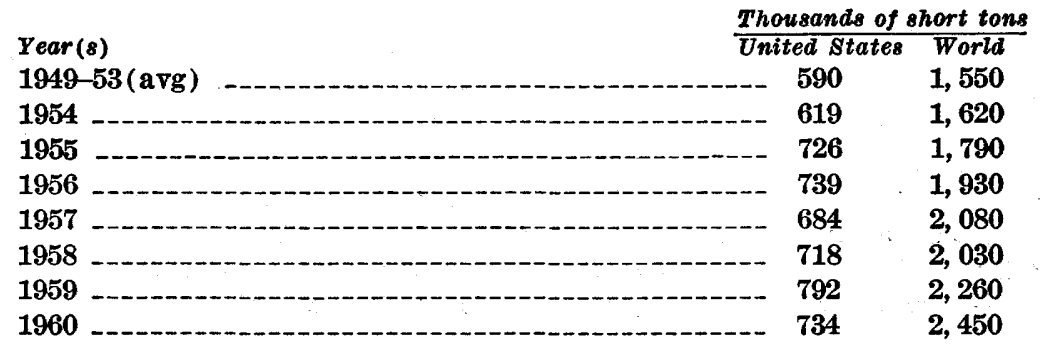




\section{SELECTED BIBLIOGRAPHY}

Albanese, J. P., 1950, A peridotite body in the Laramie Mountains, Wyoming: Rocks and Minerals, v. 25, no. 1-2, p. 52-54, 71.

Albee, A. L., 1957, Bedrock geology of the Hyde Park quadrangle, Vermont: U.S. Geol. Survey Geol. Quad. Map GQ-102. Scale, 1:62,500.

American Ceramic Society, 1922-62: Am. Ceramic Soc. Bull., monthly volumes.

Avery, R. B., Conant, M. L., and Weissenborn, H. F., 1958, Selected annotated bibliography of asbestos resources in United States and Alaska: U.S. Geol. Survey Bull. 1019-L, p. 817-865.

Bailey, R. K., 1949, Talc in the salines of the potash field near Carlsbad, New Mexico : Am. Mineralogist, v. 34, nos. 9-10, p. 757-759.

Bain, G. W., 1934, Discussion of : The problem of serpentinization, etc., by H. H. Hess (1933b) : Econ. Geology, v. 29, no. 4, p. 397-400.

- 1936, Serpentinization of Vermont ultrabasics: Geol. Soc. America Bull., v. 47, p. 1961-1980.

- 1942, Vermont talc and asbestos deposits, in Newhouse, W. H., ed., Ore deposits as related to structural features: Princeton Univ. Press, p. 255-258.

Barnes, V. E., 1940, Serpentine and associated minerals of Gillespie and Blanco Counties, Texas: Texas Univ. Bur. Econ. Geology Min. Res. Circ. 14, 5 p.

- 1946, Soapstone and serpentine in the central mineral region of Texas, in Texas mineral resources: Texas Univ. Pub. 4301, p. 55-91.

- 1952, Blowout quadrangle, Gillespie and Llano Counties, Texas: Texas Univ. Bur. Econ. Geology Geol. Quad. Maps.

Barnes, V. E., and Mathis, R. W., 1942, Soapstone of northeastern Gillespie County, Texas : Texas Univ. Bur. Econ. Geol. Min. Res. Survey Circ. 55, 10 p.

Barnes, V. E., Shock, D. A., and Cunningham, W. A., 1950, Utilization of Texas serpentine: Texas Univ. Bur. Econ. Geology Pub. 5020, 52 p.

Bassett, W. M., 1959, Structural classification of the sheet silicate minerals: New York Acad. Sciences Trans., ser. 2, v. 21, no. 7, p. 566-571.

Bates, T. F., and Mink, J. F., 1950, Morphology and structure of serpentine minerals : Pennsylvania State College, School of Mineral Industries Tech. Rept. 3, Proj. NR081-098, 30 p.

Bayley, W. S., 1941, Pre-Cambrian geology and mineral resources of the Delaware Water Gap and Easton quadrangles, New Jersey and Pennsylvania: U.S. Geol. Survey Bull. 920, 98 p.

Beckwith, R. H., 1939, Asbestos and chromite deposits of Wyoming: Econ. Geology, v. 34, no. 7, p. 816, 821-822, 837 .

Bennington, K. O., 1956, Role of shearing stress and pressure in differentiation as illustrated by some mineral reactions in the system $\mathrm{MgO}_{-} \mathrm{SiO}_{2}-\mathrm{H}_{2} \mathrm{O}$ : Jour. Geology, v. 64, p. 558-577.

Benson, W. N., 1918, The origin of serpentine-a history and comparative study: Am. Jour. Sci., 4th ser., v. 46, p. 683-731.

Betz, G. C., 1933, Improving kiln furnaces with talc: Ceramic Age, 21, p. 104-125. Bevan, Arthur, 1942, Virginia's war mineral resources: Virginia Geol. Survey Rep. Ser. 4, p. 14-15 (unnumbered lines) ; The Commonwealth, v. 9, no. 1, p. $9-12,19 ;$ no. 2 , p. 11-15, 48.

Bhushan, B., and Roy, H. N., 1956, Low expansion vitrified bodies from Indian tales: Indian Ceramic Soc. Trans., v. 15, no. 2, p. 97-113.

Billings, M. P., 1956, Geology of New Hampshire, pt. 2 of Bedrock Geology: Concord, N. H., New Hampshire State Plan. Comm., 203 p. 
Billings, M. P., and Chidester, A. H., 1948a, Geologic and structure maps, Eastern Magnesia Talc Company, Waterbury Mine, Moretown, Vermont: U.S. Geol. Survey Prelim. Map 3-225, 5 sheets. Scale, $1: 960$.

1948b, Geologic maps of Barnes Hill talc prospect, Waterbury, Vermont, Hammondsville talc quarry, Reading, Vermont, and Vermont talc Company quarry, Windham, Vermont: U.S. Geol. Survey Prelim. Map 3-224, 3 geol. maps. Scales, 1:600, 1:360 (See modifications by Chidester, Stewart, and Morris, 1950.)

Birch, R. E., and Harvey, F. A., 1935, Forsterite and other magnesium silicates as refractories: Am. Ceramic Soc. Jour., v. 18, no. 6, p. 176-192.

Blondel, F., and Lasky, S. G., 1956, Mineral reserves and mineral resources: Econ. Geology, v. 51, p. 686-697.

Bloomer, R. O., and Werner, H. J., 1955, Geology of the Blue Ridge region in central Virginia : Geol. Soc. America Bull., v. 66, no. 5, p. 593.

Bowles, Oliver, and Justice, C. W., 1933, Growth and development of the nonmetallic mineral industry : U.S. Bur. Mines Inf. Circ. 6687, 50 p.

Bowen, N. L., 1940, Progressive metamorphism of siliceous limestone and dolomite: Jour. Geology, v. 58, p. 225-274.

Bowen, N. L., and Tuttle, O. F., 1948, Serpentine and talc equilibria [abs.] : 18th Internat. Cong., London, Volume of titles and abstracts, p. 4. (Published in full as "The System $\mathrm{MgO}-\mathrm{SiO}_{2}-\mathrm{H}_{2} \mathrm{O}$ " in Geol. Soc. America Bull., v. 60, no. 3, p. 439-460.)

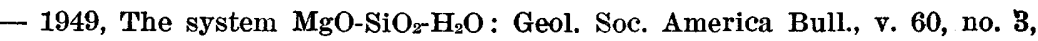
p. 439-460. (See also v. 58, Dec. 1948.)

Brindley, G. W., 1954, X-ray study of a new variety of serpentine (ortho-antigorite), in Swineford and Plummer, eds., Clays and clay minerals : Natl. Research Council Pub. 327, p. 360-363.

Brindley, G. W., and Zussman, J., 1957, A structural study of the thermal transformation of serpentine minerals to forsterite: Am. Mineralogist, v. 42, no. $7-8$, p. $461-474$.

Brown, J. S., and Engel, A. E. J., 1956, Revision of Grenville stratigraphy and structure in the Balmat-Edwards district, northwest Adirondacks, New York: Geol. Soc. America Bull., v. 67, p. 1599-1622.

Brown, W. R., 1954, Structural frame work and mineral resources of the Virginia Piedmont: Virginia Geol. Survey Repr. Ser. 16, p. 88-111; reprinted from Kentucky Geol. Survey Spec. Pub. 1, 1953.

Bryson, H. J., 1932, Nonmetallic mineral resources of North Carolina: Pit and Quarry, v. 24, no. 10, p. 17-22.

1937, The mining industry in North Carolina from 1929 to 1936 : North Carolina Dept. Conserv. Devel. Econ. Paper 64, 137 p.

1938, Ceramic raw products of North Carolina: Manufacturers Record, v. 107 , no. 5 , p. 34-56.

Buddington, A. F., 1926, Geology of the Lake Bonaparte quadrangle [New York] : New York State Mus. Bull. 269. Scale, 1: 62, 500.

Burchfiel, B. M., 1935, Ceramic raw materials: Chem. Metall. Eng., v. 42, no. 8, p. $435,436$.

1936, Ceramic materials other than clays abundant in California: Mining and Metallurgy, v. 17, no. 357, p. 441-443; 1937, Year Book 1936, p. 65 [abs.].

Burfoot, J. D., Jr., 1930, The origin of the talc and soapstone deposits of Virginia : Econ. Geology, v. 25, no. 8, p. 805-826.

686-495-63-2 
Burfoot, J. D., Jr., 1932, Talc and soapstone deposits of Virginia, in Northern Virginia : Internat. Geol. Cong., 16th, Washington 1933, Guidebook 11, Excursion $B-6$, p. 36-43.

1938, Comparative study of origin of talc and soapstone deposits of Virginia : Geol. Soc. America Bull., v. 49, no. 12, pt. 2, p. 1946.

Cady, W. M., 1956, Bedrock geology of the Montpelier quadrangle, Vermont: U.S. Geol. Survey Geol. Quad. Map GQ-79. Scale 1:62, 500.

Cady, W. M., Albee, A. L., and Chidester, A. H., 1963, Bedrock geology and asbestos deposits of the upper Missisquoi Valley and vicinity, Vermont: U.S Geol. Survey Bull. 1122-B. (In press.)

Cady, W. M., Albee, A. L., and Murphy, J. F., 1962, Bedrock geology of the Lincoln Mountain quadrangle, Vermont: U.S. Geol. Survey Geol. Quad. Map GQ-164.

California Division of Mines, 1956, Talc: California Div. Mines Mineral Inf. Serv., v. 9, no. 11, p. 1-6.

Carl, H. F., 1946, Study of firing failure in massive talc: U.S. Bur. Mines Rept. Inv. $3800,9 \mathrm{p}$.

Chawner, W. D., 1934, Discussion of : The problem of serpentinization by H. H. Hess (1933b) : Econ. Geology, v. 29, no. 8, p. 777-778.

Chidester, A. H., 1953, Geology of the talc deposits, Sterling Pond area, Stowe, Vermont: U.S. Geol. Survey Mineral Inv. Field Studies Map MF-11. Scale, 1: 2,400. (Geol. map with block diagram and text.)

- 1959, Stealization of sepentinite bodies in north-central Vermont: U.S. Geol. Survey open-file report, $71 \mathrm{p}$.

1962, Petrology and geochemistry of selected talc-bearing ultramafic rocks and adjacent country rocks in north-central Vermont: U.S. Geol. Survey Prof. Paper 345, 207 p.

Chidester, A. H., Billings, M. P., and Cady, W. M., 1951, Talc investigations in Vermont, preliminary report: U.S. Geol. Survey Circ. 95, 33 p., map.

Chidester, A. H., Engel, A. E. J., and Wright, L. A., 1963, Talc resources of the United States: U.S. Geol. Survey Bull. 1167. (In press.)

Chidester, A. H., Stewart, G. W., and Morris, D., 1952a, Geologic map of the Barnes Hill talc prospect, Waterbury, Vermont: U.S. Geol. Survey Mineral Inv. Field Studies Map MF-7. Scale, about $1: 12,000$.

1952b, Geologic map of the Rousseau talc prospect, Cambridge, Vermont: U.S. Geol. Survey Mineral Inv. Field Studies Map MF-8. Scale, about $1: 12,000$.

Chidester, A. H., and Worthington, H. W., 1962, Talc and soapstone in the United States, exclusive of Alaska and Hawaii: U.S. Geol. Survey Mineral Inv. Resource Map MR-31.

Christman, R. A., 1959, Geology of the Mount Mansfield quadrangle, Vermont: Vermont Geol. Survey Bull., no. 12, 75 p.

Clark, W. P., 1899, The relations of Maryland topography, climate, and geology to highway construction: Maryland Geol. Survey, v. 3, pt. 2, p. 47-106.

Clemmer, J. B., and Cooke, S. R. B., 1936, Flotation of Vermont talc-magnesite ores : U.S. Bur. Mines Rept. Inv. 3314, 12 p.

Comefero, J. E., Breedlove, J. G., and Thurnauer, Hans, 1954, Phosphate-bonded talc; a superior block-talc substitute: Am. Ceramic Soc. Jour., v. 37, no. 4, p. 191-195.

Crickmay, G. W., 1936, Talc deposits of Georgia : Forestry-Geol. Rev., v. 6, no. 11, p. 7-8. 
Cushing, H. P., and Newland, D. H., 1925, Geology of the Gouverneur quadrangle, New York: New York State Mus. Bull. 259, 122 p.

Dake, N. C., 1934, Geology of the Russell quadrangle [New York] : New York State Mus. Circ. 15 . Scale, $1: 84,480$.

Dart, Denis, 1959, A talc-schist deposit near Nemo, South Dakota [abs.] : South Dakota Acad. Sci. Proc., v. 38, p. 70.

Darton, N. H., Stephenson, L. W., and Gardner, J. A., 1937, Geologic map of Texas: U.S. Geol. Survey. Scale, $1: 500,000$.

Deer, W. A., Howie, R. A., and Zussman, J., 1962, Rock-forming minerals, v. 3, sheet silicates : New York, John Wiley \& Sons, $270 \mathrm{p}$.

Delaney, J. P., 1940, Variation of elastic constants with moisture in soapstone: Am. Geophys. Union Trans., 21st Ann. Mtg., pt. 1, p. 696-698.

Dietrich, J. W., and Lonsdale, J. T., 1958, Mineral resources of the Colorado River Industrial Development Association area: Texas Bur. Econ. Geology Rept. Inv. 37, p. 9, 11, 69-72.

Dillender, R. D., Jr., and Gower, I. W., 1953, Preliminary report on the froth flotation of Wake County talc: North Carolina State College Dept. Eng. Resources Indus. Inf. Ser. Bull. 7, 16 p.

Diller, J. W., 1909, Talc and soapstone in 1908: U.S. Geol. Survey Mineral Resources U.S., 1908, pt. 2, p. 869-878.

1911a, Talc and soapstone in 1909 : U.S. Geol. Survey Mineral Resources U.S., 1909, pt. 2, p. 915-923.

1911b, Talc and soapstone in 1910 : U.S. Geol. Survey Mineral Resources

U.S., 1910, pt. 2, p. 977-986.

1912, Talc and soapstone in 1911: U.S. Geol. Survey Mineral Resources

U.S., 1911, pt. 2, p. 1197-1203.

1913, Tale and soapstone in 1912 : U.S. Geol. Survey Mineral Resources

U.S., 1912, pt. 2, p. 1133-1160.

1914, Talc and soapstone in 1913 : U.S. Geol. Survey Mineral Resources

U.S., 1913, pt. 2, p. 153-163.

1916, Talc and soapstone in 1914: U.S. Geol. Survey Mineral Resources

U.S., 1914, pt. 2, p. 151-157.

1917, Talc and soapstone in 1915: U.S. Geol. Survey Mineral Resources

U.S., 1915, pt. 2, p. 61-64.

1919a, Talc and soapstone: U.S. Geol. Survey Bull. 666-I, 2 p.

$1919 \mathrm{~b}$, Talc and soapstone in 1916 : U.S. Geol. Survey Mineral Resources

U.S., 1916, pt. 2, p. 25-28.

1920a, Talc and soapstone in 1917 : U.S. Geol. Survey Mineral Resources

U.S., 1917, pt. 2, p. 81-84.

1920b, Talc and soapstone in 1918: U.S. Geol. Survey Mineral Resources U.S., 1918, pt. 2, p. 557-563.

1921, Talc and soapstone in 1919: U.S. Geol. Survey Mineral Resources U.S., 1919, pt. 2, p. 265-268.

Diller, J. S., Fairchild, J. G., and Larsen, E. S., 1920, High-grade tale for gas burners : Econ. Geology, v. 15, no. 8, p. 665-673.

Doll, C. G., Cady; W. M., Thompson, J. B., Jr., and Billings, M. P., 1961, Geologic map of Vermont: Vermont Devel. Dept. Geol. Survey. Scale, $1: 250,000$.

Dresser, J. A., 1934, Discussion of: The problem of serpentinization, $b y \mathbf{H}$. H. Hess (1933b) : Econ. Geology, v. 29, p. 306-307.

Du Rietz, Torsten, 1935, Peridotite, serpentines and soapstones in northern Sweden : Geol. Fören. Stockholm Förh. 401, v. 57, no. 2, p. 133-260. 
Eagle, J. E., 1947, Block talc: Am. Ceramic Soc. Bull., no. 26, p. 272-274.

Efremov, Nicholas, 1953, Chemical constitution of saponites, bowlingites, sauconite [abs.] : Geol. Soc. America Bull., v. 64, no. 12, pt. 2, p. 1505.

- 1954, Coefficient of geochemical oxidation as an index of degree of serpentinization of ultrabasic rocks [abs.]: Geol. Soc. America Bull. v. 65, no. 12, pt. 2, p. 1374.

Emerson, B. K., 1917, Geology of Massachusetts and Rhode Island: U.S. Geol. Survey Bull. 597, p. 85, 214-215.

Engel, A. E. J., 1947, The talc deposits of the Gouverneur district, New York [abs.] : Econ. Geology, v. 42, no. 4, p. 419.

1949a, Talc and ground soapstone, in Industrial minerals and rocks, 2d ed. : New York, Am. Inst. Mining Metall. Engineers, p. 1018-1041.

1949b, New York talcs, their geological features, mining, milling, and uses: Mining Eng., v. 1, no. 9, p. 345-458.

1962, The Precambrian geology and talc deposits of the Balmat-Edwards district, northwest Adirondack Mountains, New York: U.S. Geol. Survey open-file report, 357 p., 31 pls., 22 figs., 33 tables.

Engel, A. E. J., and Wright, L. A., 1960, Talc and soapstone, in Industrial minerals and rocks, 3rd ed : New York, Am. Inst. Mining, Metall., and Petroleum Engineers, p. 835-850.

Ewell, R. H., Bunting, E. N., and Geller, R. F., 1935, Thermal decomposition of talc: [U.S.] Natl. Bur. Standards Jour. Research, 15, p. 551-556.

Faust, G. T., and Fahey, J. J., 1962, The serpentine-group minerals : U.S. Geol. Survey Prof. Paper 384-A.

Faust, G. T., and Murata, K. J., 1953, Stevensite, redefined as a member of the montmorillonite group [New Jersey]: Am. Mineralogist, v. 38, no. 11-12, p. 973-987.

Ferguson, M. B., 1926, Electrical resistance of refactory materials : Canadian Chem. Metallurgy, v. 10, no. 6, p. 131-136.

Fisher, J. R., and Potter, J. F., 1956, Apparent density as a means for evaluating the physical structure of steatite: Am. Ceramic Soc. Bull., v. 35, no. 9, p. 356-360.

Flawn, P. T., 1958, Texas miners boost talc output: Eng. Mining Jour., v. 159, p. 104-105.

Foshag, W. F., and Wherry, E. T., 1922, Notes on the composition of talc: Am. Mineralogist, v. 7, p. 167-171.

Frommer, D. W., and Fine, M. M., 1956, Laboratory flotation of talc from Arkansas and Texas sources: U.S. Bur. Mines Rept. Inv. 5241, 5 p.

Furcron, A. S., 1935, James River iron and marble belt, Virginia : Virginia Geol. Survey Bull. 39, $125 \mathrm{p}$.

Furcron, A. S., and Teague, K. H., 1947, Talc deposits of Murray County, Georgia : Georgia Geol. Survey Bull. 53, 75 p.

Gay, T. E., Jr., and Wright, L. A., 1954, Geology of the Talc City area, Inyo County, map sheet 12 in Jahns, R. H., ed., Geology of southern California : California Div. Mines Bull. 170. Scale, about 1 in. to 2,000 ft.

Georgia Division of Mines, Mining, and Geology, 1939, Geologic Map of Georgia : Georgia Div. Mines, Mining and Geology. Scale, 1: 500,000.

Gillson, J. L., 1927, Origin of the Vermont talc deposits, with a discussion of the formation of talc in general : Econ. Geology, v. 22, p. 246-287.

1937, Talc, soapstone and pyrophyllite, in Industrial minerals and rocks, nonmetallics other than fuels: Am. Inst. Min. Metall. Engineers, p. 873-892. 
Gilluly, James, 1945, Geologic map of the Gouverneur talc district, New York: U.S. Geol. Survey Mineral Inv. Prelim. Map 3-163. Scale, $1: 48,000$.

Gleason, J. M., 1946, Steatite for high-frequency insulation: Jour. British Inst. Radio Engineers, v. 6, p. 20-32.

Gordon, S. G., 1921, Desilicated granite pegmatites: Proc. Acad. Nat. Sci. Philadelphia, pt. 1, p. 176-180.

Gottlieb, Sidney, 1943, Beneficiation of domestic tales: Am. Ceramic Soc. Bull. 22 , no. 7, p. 223-225.

Gower, I. W., and Bell, W. C., 1956, The use of pyrophyllite in castable and plastic refractories: Am. Ceramic Soc. Bull., v. 35, no. 7, p. 259-264.

Greaves-Walker, A. F., 1945, Investment opportunities in North Carolina minerals : North Carolina State Coll. Eng. Exper. Sta. Bull. 31, 29 p.

Greaves-Walker, A. F., and Riggs, S. G., Jr., 1937, The location and distribution of the ceramic mineral deposits of North Carolina: North Carolina Univ. Eng. Exper. Sta. Bull. 14, 60 p.

Gruner. J. W., 1934, Crystal structures of talc and pyrophyllite : Zeitschr. Krist., 88 A, p. $412-419$.

Grigorev, D. P., 1937, On the so-called "fusion temperatures" of sereral minerals: Soc. Russe Minér. Mém., v. 66, no. 4, p. 672-676.

Gunzenhauser, A., 1941, Steatite and special ceramic materials; their development, application and manufacture : Ceramic Industry, v. 37, p. 41-46.

Hall, W. E., 1948, Structure and ore deposits of the Darwin quadrangle, Inyo County, California : U.S. Geol. Survey open-file report, $153 \mathrm{p}$.

Hall, W. E., and Mackevett, E. M., 1958, Economic geology of the Darwin quadrangle, California : California Div. Mines Spec. Rept. 51, 73 p.

Hart, J. R., 1954, The use of North Carolina talc in steatite bodies [abs.] : Am. Ceramic Soc. Bull., v. 33, no. 4, p. 27.

Hauser, E. A., and Le Beau, D. S., 1946, Colloid chemistry of clay minerals and clay films : Colloid Chemistry, 6, p. 191-213.

Heinrich, E. W., 1947, Petrology of the Montana pre-Cambrian carbonate rocks [abs.] : Geol. Soc. America Bull., v. 58, no. 12, pt. 2, p. 1191.

Hendricks, S. B., and Jefferson, M. E., 1938, Structures of kaolin and talc-pyrophyllite hydrates and their bearing on water sorption of the clays: Am. Mineralogist, v. 23, p. 863-875.

Hess, H. H., 1933a, Hydrothermal metamorphism of an ultrabasic instrusive at Schuyler, Virginia : Am. Jour. Sci., 5th ser., v. 26, no. 154, p. 377-408.

$1933 \mathrm{~b}$, The problem of serpentinization and the origin of certain chrysotile asbestos, talc, and soapstone deposits : Econ. Geology, v. 28, no. 7, p. 634-657. (See also Bain, 1934 ; Chawner, 1934 ; Dresser, 1934.)

1935, Reply to Discussion of The problem of serpentinization, etc. by Hess : Econ. Geology, v. 30, no. 3, p. 320-325. (See also Hess, 1933b ; Bain, 1934 ; Chawner, 1934 ; Dresser, 1934.)

- 1955, Serpentines, orogeny, and epeiorogeny, in Poldervaart, Arie, ed., Crust of the Earth : Geol. Soc. America Spec. Paper 62, p. 391-408.

Hickok, K. E., 1940, Nonmetallic minerals: Mines Mag. [Colorado], v. 30, p. 65-66, 74.

Hietanen, A. M., 1951, Metamorphic and igneous rocks of the Merrimac area, Plumas National Forest, California: Geol. Soc. America Bull., v. 62, no. 6, p. 565-607.

Hitchcock, C. H., 1878, Atlas accompanying the report on the geology of New Hampshire: Concord, N. H., E. A. Jenks, State printer. 
Hitchcock, Edward, Hitchcock, Edward, Jr., Hager, A. D., and Hitchcock, C. H., 1861, Report on the geology of Vermont: descriptive, theoretical, economical and scenographical: Claremont, N. H., v. 1, p. 533-555; v. 2, p. 778-780, 783, 791.

Hopkins, H. R., 1957, Nelson-Amherst soapstone belt: Virginia Div. Mineral Res. Prelim. Map.

Hopkins, O. B., 1914, A report on the asbestos, talc, and soapstone deposits of Georgia : Georgia Geol. Survey Bull. 29, 319 p.

Hudspeth, W. R., Adair, R. B., and Sales, P. N., 1952, Beneficiation of stained talc: North Carolina Univ. State Coll. Agric. and Engineering, Minerals Res. Lab. Rept. Inv. 2.

Hughes, H. H., 1932, Soapstone : U.S. Bur. Mines Inf. Circ. 6563.

Hunter, C. E., 1941, Forsterite olivine deposits of North Carolina and Georgia : North Carolina Dept. Conserv. Devel. Bull. 41, 117 p.

Hunter, C. E., and Gildersleeve, Benjamin, 1946, Minerals and structural materials of western North Carolina and north Georgia: Tennessee Valley Authority, Regional Products Research Div. Rept. C., 94 p.

Hurley, P. M., and Thompson, J. B., 1950, Airborne magnetometer and geological reconnaissance survey in northwestern Maine: Geol. Soc. America Bull., v. 61, p. 835-842.

Industrial Publications, 1923-62: Ceramic Industry, monthly volumes.

Irving, D. R., 1960, Talc, soapstone, and pyrophyllite: U.S. Bur. Mines Bull. 556, p. $835-843$.

Jacobs, E. C., 1914, Talc and the tale deposits of Vermont: Vermont State Geologist 9th Rept. 1913-14, p. 382-429.

1916, The talc and verde antique deposits of Vermont: Vermont State Geologist 10th Rept., 1915-16, p. 232-280.

- 1921, Progress in talc production: Vermont State Geologist 12th Rept., 1919-20, p. 101-113.

_. 1938, Geology of Green Mountains : Vermont State Geologist 21st Rept., p. 1-73.

- 1944, Report of the State Geologist on the mineral industries and geology of Vermont, 1943-44: $41 \mathrm{p}$.

James, H. L., 1946, Johnny Gulch talc deposit, Madison County, Montana : U.S. Geol. Survey open-file report, $8 \mathrm{p}$.

Jenkins, O. P., 1938, Geologic map of California : California Dept. Nat. Resources, Div. Mines. Scale, 1: 500,000.

Jicha, H. L., Jr., 1954, Paragenesis of the ores of the Palomas (Hermosa) district, southwestern New Mexico : Econ. Geology, v. 49, no. 7, p. 759-778.

Johnson, B. L., 1939, Marketing talc, pyrophyllite, and ground soapstone: U.S. Bur. Mines Inf. Circ. 7080, 13 p.

Jones, W. B., 1939, Geology of the Tennessee Valley region of Alabama, with notes on the topographic features of the area, and the effect of geology and topography upon aboriginal occupation, in Webb, William S., An archaeological survey of Wheeler basin on the Tennessee River in northern Alabama : Bur. Am. Ethnology Bull. 122, p. 9-20.

Julien, A. A., 1914, The genesis of antigorite and talc: New York Acad. Sci. Annals 24, p. 23-38.

Keith, Arthur, 1903, Talc deposits of North Carolina: U.S. Geol. Survey Bull. 213, p. 433-438.

1904, Description of the Ashville quadrangle [North Carolina-Tennessee] : U.S. Geol. Survey Atlas, Folio 116, 10 p., 4 maps. 
Keith, Arthur, 1905, Description of the Mount Mitchell quadrangle [North Carolina-Tennessee] : U.S. Geol. Survey Atlas, Folio 124, 10 p., 4 maps.

1907, Description of the Nantahala quadrangle [North Carolina-Tennessee] : U.S. Geol. Survey Atlas, Folio 143, 12 p., 4 maps.

Keith, S. B., and Bain, G. W., 1932, Chrysotile asbestos; pt. 1, Chrysotile veins : Econ. Geology, v. 27, no 2, p. 169-188.

King, P. B., and Flawn, P. T., 1953, Geology and mineral deposits of pre-Cambrian rocks of the Van Horn area, Texas: Texas Univ. Pub. 5301, p. 170-172.

King, P. B., Hadley, J. B., Neuman, R. B., and Hamilton, Warren, 1958, Stratigraphy of Ocoee series, Great Smoky Mountains, Tennessee and North Carolina: Geol. Soc. America Bull., v. 69, p. 947-966.

King, R. M., 1935, Talc as a ceramic body ingredient: Ceramic Industry, v. 25, p. 70-71.

King,, R. M., and Evans, C. L., 1933, Talc-clay mullite: Am. Ceramic Soc. Jour., v. 16, no. 8, p. 360-362.

Klinefelter, T. A., O'Meara, R. G., Smith, R. W., and Truesdell, G. G., 1947, Talc in radio ceramic insulators: Am. Inst. Mining Metall. Engineers Trans., $\nabla$. 173, p. 627-631.

Klinefelter, T. A., Speil, Sidney, and Gottlieb, Sidney, 1945, Survey of the suitability of domestic talcs for high-frequency insulators: U.S. Bur. Mines Rept. Inv. 3804, 58 p.

Kraner, H. M., and McDowell, S. J., 1925, Talc as the principal body ingredient in vitrified ceramic bodies: Am. Ceramic Soc. Jour., v. 8, no. 10, p. 626-635.

Ladoo, R. B., 1919, Talc mining in Vermont: U.S. Bur. Mines. Rept. Inv. 2026, $15 \mathrm{p}$.

1920, Talc mining in New York: U.S. Bur. Mines Rept. Inv. 2171, 15 p., 5 figs.

1923, Talc and soapstone, their mining, milling, products, and uses : U.S. Bur. Mines Bull. 213, 133 p.

Lamar, R. S., 1944a, Geology, chemistry and utility of California tales : Official Digest 238, p. 393-397.

1944b, Particle shape and differential shrinkage of steatite talc bodies: Am. Ceramic Soc. Jour., v. 27, no. 11, p. 317-320.

1952, California talc in the paint industry: California Jour. Mines and Geology, v. 48, no. 3, p. 189-199.

Lasky, S. G., 1945, The concept of ore reserves: Mining and Metallurgy, v. 26, p. $471-474$.

1950, Mineral resource appraisal by the U.S. Geological Survey : Colorado School Mines Quart., v. 45, p. 1-27.

Lemmon, J. W., 1955, Investigation of California talc for use in wall tile: Am. Ceramic Soc. Jour., v. 38, p. 418-422.

Lemmon, J. W., and Watts, A. S., 1943, Study of talc minerals in steatite bodies : Am. Ceramic Soc. Bull. 22, no. 11, p. 369-371.

Lipinski, F., 1941, Role of magnesia in ceramic bodies : Ber. Deutsch Keramisch, Gesell., จ. 22, no. 8, p. 286-292.

Luedke, E. M., Wrucke, C. T. and Graham, J. A., 1959, Mineral occurrences of New York State with selected references to each locality. U.S. Geol. Survey Bull. 1072-F.

McCallie, S. W., 1910, A preliminary report on the mineral resources of Georgia : Georgia Geol. Survey Bull. 23, 208 p.

McConnell, Duncan, 1954, Ortho-antigorite and the tetrahedral configuration of hydroxyl ions: Am. Mineralogist, v. 39, no. 9-10, p. 830-831. 
McDonald, G. A., 1941, Geology of the western Sierra Nevada between the Kings and San Joaquin Rivers, California : California Univ. Dept. Geol. Sci. Bull., v. 26, no. 2, p. 215-286.

McGill, W. M., 1936, Outline of mineral resources of Virginia : Virginia Geol. Survey Bull. 47, p. 61-63.

McMurray, L. L., and Bowles, E. O., 1941, The talc deposits of Talladega County, Alabama : Alabama Geol. Survey Circ. 16, 31 p.

Mamykin and Permyakov, 1931, Talc as a refractory: Ural. Tehnik, v. 7, no. 1, p. 12-17.

Marsters, V. F., 1904, A preliminary report on a portion of the serpentine belt of Lamoille and Orleans Counties: Vermont State Geologist 4th Rept. 1903-04, p. 86-102.

Maynard, T. P., Mallory, J. M., and Still, R. T., 1923, Direction of commercial minerals in Georgia and Alabama along the Central of Georgia Railway: Issued by Central of Georgia Railway Indus. Dept., Savannah.

Merrill, F. H., 1901, Geologic map of New York: New York State Museum. Scale, $1: 316,800$.

Merten, Hermann, 1936, Talc deposits of Washington: The Mineralogist, v. 4, no. 8, p. $12,22$.

Midwest Research Institute, 1946, Mineral resources of Nebraska, Iowa, Kansas, Missouri, Oklahoma, Arkansas : Midwest Res. Inst., Kansas City, Mo. Scale, $1: 1,250,000$.

Miller, B. L., Fraser, D. M., and Miller, R. L., 1939, Northampton County, Pennsylvania; Geology and geography by B. L. Miller, Pre-Cambrian geology by D. M. Fraser, Jacksonburg formation by R. L. Miller: Pennsylvania Geol. Survey Bull. C-48, 4th ser., 496 p.

Miller, Roswell, III, 1953, The Webster-Addie ultramafic ring, Jackson County, North Carolina, and secondary alteration of its chromite: Am. Mineralogist, v. 38, no. 11-12, p. 1134-1147.

Mitchell, F. B., 1944, Talc, steatite, and soapstone: Mine and Quarry Eng., v. 9, p. 66-70.

?

Moneymaker, B. C., 1938, Discussion of: Talc deposits of North Carolina by J. L. Stuckey : Econ. Geology, v. 33, p. 461-463.

Montgomery, Arthur, 1955, Paragenesis of the serpentine-talc deposits near Easton, Pennsylvania : Pennsylvania Acad. Sci. Proc., v. 29, p. 203-215.

Moore, J. R., III, 1947, Central Texas, the rockhounds' playground: Rocks and Minerals, v. 22, no. 5, p. 413.

Moriyasu, S., 1937, Electrical resistance of talc-kaolin system: Jour. Japanese Ceramic Assoc., 45, p. 1-8.

Murdock, T. G., 1946, Mineral raw materials for roofing manufacture; roofing manufacturing opportunities in North Carolina : North Carolina Dept. Conserv. Devel., Div. Min. Resources, Resource-Industry Ser. 2, 26 p.

Murphy, F. W., 1932, Geology of a part of Panamint Range: California Div. Mines Rept. 28, p. 329-356, p. 330. Scale, $1: 125,000$.

Myers, T. R., and Steward, G. W., 1946, Geology of New Hampshire, pt. 3 of Minerals and Mines: Concord, N. H., New Hampshire State Planning Commission, $107 \mathrm{p}$.

Nagy, Barthalomew, 1953, The textural pattern of the serpentines: Econ. Geology, v. 48, no. 7, p. 591-597.

Nagy, Barthalomew, and Bates, T. F., 1952, Mineralogy of the serpentine group [abs.] : Geol. Soc. America Bull., v. 64, no. 12, pt. 2, p. 1285; Am. Mineralogist, v. 38, no. 3-4, p. 355, 1955. 
Nevius, J. N., 1899a, Fibrous talc in St. Lawrence County, New York: Eng. Min. Jour., v. 67, p. 234-235.

1899b, The talc industry of St. Lawrence County [New York] : New York State Mus. Ann. Rept. 51, p. 119-127.

Newland, D. H., 1921, The mineral resources of the State of New York: New York State Mus. Bull., nos. 223, 224, 315 p.

Norman, J. E., O'Meara, R. G., and Baumert, F. X., 1939, Froth flotation of talc ores from Gouverneur, New York: Am. Ceramic Soc. Jour., v. 18, no. 8, p. 292-297.

Olson, J. C., 1944, Economic geology of the Spruce Pine pegmatite district, North Carolina: North Carolina Dept. Conserv. Devel. Bull. 43, pt. 1, 67 p.

Osberg, P. H., 1952, The Green Mountain anticlinorium in the vicinity of Rochester and East Middlebury, Vermont: Vermont Geol. Survey Bull. 5, 127 p.

Osterwald, F. W., and Osterwald, D. B., 1952, Wyoming mineral resources: Wyoming Geol. Survey Bull. 45, p. 159-160.

Osterwald, F. W., Osterwald, D. B., Long, J. S., Jr., and Wilson, W. H., 1959, Mineral resources of Wyoming: Wyoming Geol. Survey Bull. 50, $259 \mathrm{p}$.

Page, B. M., 1942, The Reed talc mine, Esmeralda County, Nevada: U.S. Geol. Survey open-file report.

1951, Talc deposits of steatite grade, Inyo County, California : California Div. Mines Spec. Rept. 8, 35 p.

Pask, J. A., and Warner, M. F., 1954, Constitution of talcs, pt. 1 of Fundamental studies of talc: Am. Ceramic Soc. Jour., v. 37, no. 3, p. 118-128.

Pearre, N. C., 1956, Mineral deposits and occurrences in Massachusetts and Rhode Island, exclusive of clay, sand and gravel, and peat: U.S. Geol. Survey Mineral Inv. Resource Map MR-4.

1957, Mineral deposits and occurrences in Connecticut, exclusive of clay, sand and gravel, and peat: U.S. Geol. Survey Mineral Inv. Resource Map MR-7.

Pearre, N. C., and Calkins, J. A., 1957a, Mineral deposits and occurrences in Vermont, exclusive of clay, sand and gravel, and peat: U.S. Geol. Survey Mineral Inv. Resource Map MR-5.

1957b, Mineral deposits and occurrences in New Hampshire, exclusive of clay, sand and gravel, and peat: U.S. Geol. Survey Mineral Inv. Resource Map MR-6.

Pearre, N. C., and Heyl, A. V., 1960, Chromite and other mineral deposits in serpentine rocks of the Piedmont upland, Maryland, Pennsylvania, and Delaware : U.S. Geol. Survey Bull. 1082-K, p. 707-833 [1961].

Peck, F. B., 1905, Talc deposits of Phillipsburg, New Jersey, and Easton, Pennsylvania : New Jersey Geol. Survey Ann. Rept. 1904, p. 161-185.

1911, Preliminary report on the tale and serpentine of Northampton County and the Portland cement materials of the Lehigh district: Pennsylvania Topog. Geol. Survey Rept. 5, $66 \mathrm{p}$.

Pence, F. K., 1955, A commercially proven white-firing talc occurring in West Texas : Am. Ceramic Soc. Bull., v. 34, p. 122-123.

Perry, E. L., 1929, Geology of Bridgewater and Plymouth townships, Vermont: Vermont State Geologist 16th Rept., p. 1-64.

Perry, E. S., 1948, Talc, graphite, vermiculite, and asbestos in Montana : Montana Bur. Mines and Geology Mem. 27, pt. 1, p. 1-12.

Phillips, A. H., and Hess, H. H., 1936, Metamorphic differentiation at contacts between serpentinite and siliceous country rocks: Am. Mineralogist, v. 21, no. 6, p. $333-362$. 
Pratt, J. H., 1900, Talc and pyrophyllite deposits in North Carolina: North Carolina Geol. Survey Econ. Paper 3, 29 p.

Pratt, J. H., and Lewis, J. V., 1905, Corundum and peridotites of western North Carolina : North Carolina Geol. Survey [Rept.], v. 1, p. 36-59.

Quinn, A. W., 1959, Bedrock geology of the Providence quadrangle, Rhode Island: U.S. Geol. Survey Geol. Quad. Map GQ-118. Scale, $1: 20,000$.

Ralston, O. C., 1938, Flotation and agglomerate concentration of nonmetallic minerals : U.S. Bur. Mines Rept. Inv. 3397, 63 p.

1944, War focuses attention on Southeast's nonmetallics : Manufacturers Rec., $\nabla .113$, no. 10, p. 52-53, 78-80.

Read, H. H., 1934, On zoned associations of antigorite, talc, actinolite, chlorite, and biotite in Unst. Shetland Islands: Mineralog, Mag., v. 23, no: 145, p. $519-540$.

Reed, A. H., Jr., 1950, Investigation of the Winterboro talc deposits, Talladega County, Alabama : U.S. Bur. Mines Rept. Inv. 4661, 7 p.

Rice, W. N., and Gregory, H. E., 1906, Manual of the geology of Connecticut: Connecticut Geol. Nat. History Survey Bull. 6, p. 100.

Roff, W. W., 1943, Western tales : Am. Ceramic Soc. Bull., v. 22, p. 292-295.

Ross, C. P., Andrews, D. A., and Irving, J. W., 1955, Geologic map of Montana : U.S. Geol. Survey. Scale, $1: 500,000$.

Roy, D. M., and Roy, Rustum, 1954a, An experimental study of the formation and properties of synthetic serpentines and related layer silicate minerals: Am. Mineralogist, v. 39, nos. 11-12, p. 957-975.

1954b, Serpentine-kaolinite family, pt. 1 of Synthesis, stability and properties of layer silicate structures [abs.] : Am. Mineralogist, v. 39, nos. 3-4, p. 340 ; Geol. Soc. America Bull., v. 64, no. 12, pt. 2, p. 1468-1469, 1953.

Ryan, C. W., 1929, Soapstone mining in Virginia: Am. Inst. Min. Metall. Eng. Tech. Pub. 160, 31 p.

Sampson, Edward, 1922a, Talc and soapstone in 1920 : U.S. Geol. Survey Mineral Resources U.S., 1920, pt. 2, p. 201-213.

1922b, Talc and soapstone in 1921: U.S. Geol. Survey Mineral Resources U.S., 1921, pt. 2, p. 97-103.

1923, Talc and soapstone in 1922 : U.S. Geol. Survey Mineral Resources U.S., 1922, pt. 2, p. 81-86.

Searle, A. B., and Grimshaw, R. W., 1959, The chemistry and physics of clays and other ceramic materials: $3 d$ ed., New York, Interscience Publishers, $942 \mathrm{p}$.

Selfridge, G. C., 1936, X-ray and optical investigations of serpentine minerals : Am. Mineralogist, v. 21, p. 463-501.

Shannon, E. U., 1926, The minerals of Idaho: U.S. Natl. Mus. Bull. 131, p. 284-285.

Skehan, J. W., 1961, The Green Mountain anticlinorium in the Vicinity of Wilmington and Woodford, Vermont: Vermont Geol. Survey Bull. 17.

Sloane, Earle, 1908, Catalogue of the mineral localities of South Carolina: South Carolina Geol. Survey Bull. 2, ser. 4, p. 122-125.

Smith, G. O., Bastin, E. S., and Brown, C. W., 1907, Description of the Penobscot Bay quadrangle [Maine] : U.S. Geol. Survey Geol. Atlas, Folio 149, p. 8-9.

Smith, J. W., 1961, Talc, soapstone, and related stone deposits of Virginia: Virginia Minerals, v. 7, no. 2, 8 p.

Smyth, C. H., 1896, The genesis of the talc deposits of St. Lawrence County, New York: New York School Mines Quart., v. 17, p. 332-341. 
Spence, H. S., 1940, Talc, steatite, and soapstone: pyrophyllite: Canada Mines and Geology Branch Pub., 803.

Stemple, I. S., and Brindley, G. W., 1960, A structural study of tale and taletremolite relations: Am. Ceramic Soc. Jour., v. 43, no. 1, p. 34-42.

Stose, G. W., and Jonas, A. I., 1939, Geology and mineral resources of York County, Pennsylvania: Pennsylvania Geol. Survey, 4th ser., Bull. C-67.

Stuckey, J. L., 1937, Talc deposits of North Carolina : Econ. Geology, v. 32, p. 1009-1018. (See Moneymakers, 1938.)

1942, Prophyllite deposits of North Carolina, in Newhouse, W. H., ed., Ore deposits as related to structural features: Princeton Univ. Press, p. 170-171.

1949, Talc and soapstone in North Carolina [abs.] : North Carolina Acad. Sci. Proc., in Elisha Mitchell Sci. Soc. Jour., v. 65, no. 2, p. 195.

1950, Talc, soapstone, and pyrophyllite in the southeastern United States, in Snyder, F. G., ed., Symposium on mineral resources of the southeastern United States : p. 112-119.

- 1958, Resources and utilization of North Carolina pyrophyllite: Mining Eng., v. 10, no. 1, p. 97-99: Am. Inst. Mining, Metall. and Petroleum Eng. Trans., v. 211, 1958, p. 97-99.

Stuckey, J. L., and George, D. R., 1940, Soapstone deposits in Wake County [North Carolina]: North Carolina Acad. Sci. Proc., in Elisha Mitchell Sci. Soc. Jour., v. 56, no. 2, p. 225.

Stuckey, J. L., Hunter, C. E., and Murdock, T. G., 1947, Industrial minerals of North Carolina ; pegmatites worked for many products: Mining and Metallurgy, v. 28, no. 487, p. 321-325, index maps.

Stuckey, J. L., and Steel, W. G., 1953, Geology and Mineral Resources of North Carolina : North Carolina Dept. Conserv. Devel., Educational Ser. 3.

Swanson, R. W., 1950, Geology of a part of the Virginia City and Eldridge quadrangles [Montana] : U.S. Geol. Survey open-file report. Scale, 1: 62,500.

Taber, S., 1916, The genesis of asbestos and asbestiform minerals: Am. Inst. Mining Metall. Engineers Trans., v. 57, p. 62-98.

Teague, K. H., 1946, Georgia talc industry helped by geologic study : Eng. Mining Jour., v. 147, no. 11, p. 63-65.

— 1950, Georgia's tale industry [abs.] : Georgia Acad. Sci. Bull., v. 8, no. 1, p. 13.

Thilo, E., 1933, Chemical investigations of silicates: pt. 1, Behavior of pyrophyllite toward $\mathrm{MgCl}_{2}$ and $\mathrm{MgO}$; Zeitsch. anorg. $\mathrm{u}$. allg. Chemia 212, p. $369-376$.

Thilo, E., and Rogge, G., 1939, Chemical investigation of silicates : pt. 8, Thermal transformation of anthophyllite $\mathrm{Mg}_{7} \mathrm{Si}_{8} \mathrm{O}_{22}(\mathrm{OH})_{2}$; polymorphism of magnesium metasilicate and mechanism of transformation of anthophyllite and talc upon heating: Deutche chem. Gesell. Ber., 72 B, p. 341-362.

Thomas, R. G., 1951, An example of re-intrusion of serpentine: Am. Geophys. Union Trans., v. 32, no. 3, p. 462-465.

Thurnauer, Hans, 1940, Utilization of talc as a ceramic raw material: Ceramic Age 35, p. 146-148.

- 1950, High-frequency insulation: Am. Ceramic Soc. Bull., v. 29, p. 158-160. Thurnauer, H., and Rodriguez, A. R., 1942, Notes on constitution of steatite: Am. Ceramic Soc. Jour., v. 25, no. 15, p. 443-450. 
Trainer, J. N., 1940, Another year at Tilly Foster (New York mine) : Rocks and Minerals, v. 15, no. 4, p. 126-128.

1941, The fifth year at Tilly Foster (New York mine) : Rocks and Minerals, v. 16, no. 4, p. 122-126.

Treischell, C. C., 1957, Availability and control of ceramic grade talc and pyrophyllite: Am. Ceramic Soc. Bull., v. 36, no. 5, p. 177-178.

Tucker, W. B., 1927, Mineral resources of Santa Catalina Island: California State Mineralogist 23rd Rept., chap. 1, p. 32-39.

Tucker, W. B., and Sampson, R. J., 1945, Mineral resources of Riverside County [California] : California Jour. Mines and Geology, v. 41, no. 3, p. 121-182.

U.S. Bureau of Mines, 1932-62, Talc, soapstone, and pyrophyllite, in Minerals Yearbooks, 1932-61, preprints for 1962. Published annually by the U.S. Bureau of Mines.

Valentine, G. M., 1949, Inventory of Washington minerals, pt. 1 of non-metallic minerals: Washington Div. Mines and Geology Bull. 37, p. 96-97.

Van Horn, E. C., 1948, Talc deposits of the Murphy marble belt: North Carolina Div. Mineral Resources Bull. 56, 54 p.

Virginia Geological Survey, 1928, Geologic map of Virginia : Virginia Conservation and Devel. Comm., Geol. Survey. Scale, $1: 500,000$.

Vitaliano, C. J., 1957, Wall-rock alteration in the Broken Hills Range, Nevada: Jour. Geology, v. 65, no. 2.

Wade, W. R., and Wandke, Alfred, 1923, A big zinc mine in New York State at Edwards, St. Lawrence County : Eng. Mining Jour., v. 116, p. 96, 97.

Waskey, F. H., 1946, Memories of Nelson Island, Alaska: Rocks and Minerals, v. 21 , no. 6, p. 350-353.

Wasserman, Gilbert, 1956, Magnetic survey of the Staten Island serpentinite: Staten Island Inst. Arts and Sciences Proc., v. 18, p. 3-19.

White, J. S., 1944, Particle size distribution of steatite talc: Am. Ceramic Soc. Jour., v. 27, no. 11, p. 320-323.

White, W. S., and Jahns, R. H., 1950, Structure of central and east central Vermont: Jour. Geology., v. 58, p. 179-220.

Whittaker, E. J. W., and Zussman, J., 1956, The characterization of serpentine minerals by X-ray diffraction: Mineralogical Mag., v. 31, no. 233, p. 107-126.

Wigglesworth, Edward, 1916, The serpentines of Vermont: Vermont State Geologist Rept., v. 10, p. 281-292.

Wiik, H. B., 1953, Composition and origin of soapstone: Finlande Comm. Geol. Bull. 165, $57 \mathrm{p}$.

Wilson, H., and Pask, J. A., 1936a, Talc and soapstone in Washington : Am. Inst. Mining Metall. Engineers Contrib. 99, 25 p., index map.

-1936b, Tale and soapstone in Washington: Mining and Metallurgy, v. 17 , no. 350, p. 118.

Wing, L. A., 1951, Asbestos and serpentine rocks of Maine: Maine Geol. Survey, State Geologist Rept., 1949-50, p. 35-46.

Wing, L. A., and Dawson, A. S., 1949, Preliminary report on asbestos and associated rocks of northwestern Maine: Maine Geol. Survey, State Geologist Rept., 1947-48, p. 30-62.

Wright, H. D., 1960, An optical study of talc-tremolite relations: Am. Ceramic Soc. Jour., v. 43, no. 1, p. 42-43.

Wright, L. A., 1948, White Eagle talc deposit, an example of steatization of granite [abs.] : Geol. Soc. America Bull., v. 59, no. 12, pt. 2, p. 1385.

1949, Geology of the Silver Lake talc area, San Bernardino County, California [abs.] : Geol. Soc. America Bull., v. 60, ro. 12, pt. 2, p. 1932. 
Wright, L. A., 1950a, California tales: Mining Eng., v. 187, no. 1, p. 122-128; Am. Inst. Min. Metall. Engineers Trans., v. 187, p. 122-128.

1952, Geology of the Superior talc area, Death Valley, California: California Div. Mines Spec. Rept. 20, 22 p.

1953, Genesis of California tale [abs.]: Econ. Geology, v. 48, no. 4, p. 333-334.

1954, Geology of the Silver Lake talc deposits, San Bernardino County, California : California Div. Mines Spec. Rept. 38, 30 p.

1957, Tale and soapstone, in Wright, L. A., ed., Mineral commodities of California : California Div. Mines Bull. 176, p. 623-634.

Wright, L. A., Chesterman, C. W., and Norman, L. A., Jr., 1954, Occurrence and use of nonmetallic commodities in southern California, pt. 7 in Chap. 8 of Jahns, R. H., ed., Geology of southern California: California Div. Mines Bull. 170, p. 59-74.

Wright, L. A., Stewart, R. M., Gay, T. E., Jr., and Hazenbush, G. C., 1953, Mines and mineral deposits of San Bernardino County, California : California Jour. Mines and Geology, v. 49, no. 1-2, p. 197-216, tabulated list of mines and mineral deposits., p. 168-173.

Zodac, Peter, 1940, A talc quarry near Chester, Vermont: Rocks and Minerals, v. 15, no. 11, p. 369-371.

1946, McAfee, New Jersey, limestone quarry: Rocks and Minerals, v. 21, no. 7 , p. $416-417$, index map.

Zussman, J., Brindley, G. W., and Comer, J. J., 1957, Electron diffraction studies of serpentine minerals : Am. Mineralogist, v. 42, no. 3-4, p. 133-153. 



\section{INDEX}

Alabama :

Jones 1939

McMurray and Bowles 1941

Maynard and others 1928

Reed 1950

Alaska :

Waskey 1946

Arkansas :

Frommer and Fine 1956

Midwest Research Ingtitute 1946

Asbestos :

Bain 1934

Beckwith 1939

Chawner 1934

Dresser 1934

Hess 1933b, 1935

Hopkins 1914

Keith and Bain 1982

Taber 1916

Wing 1951

Wing and Dawson 1949

Bibliography :

Avery and others 1958

Chidester and Worthington 1962

Block talc :

Comefero and others 1964

U.S. Bureau of Mines 1944

California :

Area :

Merrimac: Hletanen 1951

Santa Catalina Island : Tucker 1927

Silver Lake : Wright, L. A. 1949, 1954

Superior : Wright, L. A. 1952

Talc City : Gay and Wright, L. A. 1954

Western Sierra Nevada : McDonald 1941

White Eagle : Wright, L. A. 1948

County :

Inyo :

Hall 1948

Hall and Mackevett 1958

Murphy 1932

Page 1951

Riverside: Tucker and Sampson 1945

San Bernardino: Wright, L. A., Stewart, Gay, and Hazenbush 1953

General :

Burchfiel 1936

California Div. of Mines 1856

Chidester, Engel, and Wright 1963

Jenkins 1938

Lamar 1944a

Wright, L. A. 1950

Wright, L.A., Chesterman, and Norman 1954
California-Continued

Genesis :

Chidester, Engel, and Wright 1963 Wright, I. A. 1953

Use :

$\begin{array}{lr}\text { Lamar } & 1952 \\ \text { Lemmon } & \mathbf{1 9 5}\end{array}$

Canada :

Avery and others 1958

Spence 1940

Connecticut :

Pearre 1957

Rice and Gregory 1906

Crystallography : \$ee Mineralogy.

Delaware :

Pearre and Heyl 1961

Economics :

Bowles and Justice 1933

Greaves-Walker 1945

Hall and Mackevett 1958

Hitchcock, Edward, and others 1861

Irving 1960

Johnson 1939

Lasky 1945, 1950

Olson 1944

Ralston 1944b

Sampson 1922a, 1923

U.S. Bureau of Mines 1932-60

General :

California Div, of Mines 1956

Chidester, Engel, and Wright 1963

Diller 1909, 1911a, 1912, 1913, 1914, 1916, 1917, 1919, 1920a, b, 1921

Engel 1949a

Engel and Wright, L. A. 1960

Gillson 1937

Hickok 1940

Irving 1956, 1960

Ladoo 1923

Mitchell 1944

Roff 1943

Sampson 1922a, b, 1923

Stuckey 1950

U.S. Bureau of Mines 1932-61

Geochemistry :

Brindley 1954

Chidester 1962

Comefero and others 1954

Efremov 1954

Hauser and LeBeau 1946

Selfridge $\mathbf{1 9 3 6}$

Whittaker and Zussman 1956

Wright, L. A. 1948

Geology :

Applied :

Bailey 1949 


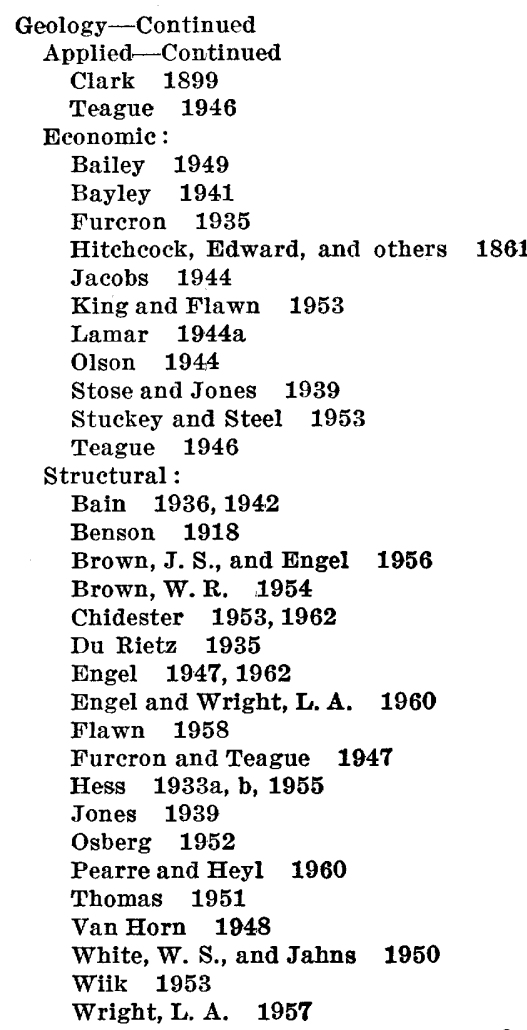

Geophysics: Hurley and Thompson 1950 Georgia :

General :

Crickmay 1936

Georgia Div. Mines, Mining, and Geology 1939

Hopkins 1914

Hunter 1941

Hunter and Gildersleeve 1946

MeCallie $\mathbf{1 9 1 0}$

Maynard and others 1923

Teague 1946, 1950

Murray County: Furcron and Teague 1947

Idaho: Shannon 1926

Maine :

Hurley and Thompson 1950

Smith, G. O., and others 1907

Wing 1951

Wing and Dawson 1949

Maps :

Geologic :

Mineral deposits :

Barnes 1946

Barnes and others 1950

Billings and Chidester 1948a, b

Chidester 1953, 1962

Chidester, Stewart, and Morris $1952 a, b$

\author{
Maps-Continued \\ Geologic-Continued \\ Mineral deposits-Continued \\ Christman 1959 \\ Dietrich and Lonsdale $\mathbf{1 9 5 8}$ \\ Engel 1962 \\ Fureron and Teague 1947 \\ Gillson 1927 \\ Hopkins, O. B. 1914 \\ James 1946 \\ King and Flawn 1953 \\ Page 1942, 1951 \\ Pearre and Heyl 1960 \\ Peck 1905 \\ Perry, E. S. 1948 \\ Pratt and Lewis 1905 \\ Reed 1950 \\ Van Horn 1948 \\ Wigglesworth 1916 \\ Wing 1951 \\ Wing and Dawson 1949 \\ Wright, L. A. 1952, 1954 \\ Quadrangle maps: See individual \\ States. \\ Regional : \\ Barnes 1946 \\ Bloomer and Werner 1955 \\ Brown, J. S., and Engel 1956 \\ Cady, Albee, and Chidester 1962 \\ Chidester, Engel, and Wright 1963 \\ Darton and others 1937 \\ Doll and others 1961 \\ Emerson 1917 \\ Engel 1962 \\ Flawn 1958 \\ Furcron and Teague 1947 \\ Gay and Wright, L. A. 1954 \\ Georgia Div. of Mines, Mining, and \\ Geology 1939 \\ Gilluly 1945 \\ Hitchcock, C. H. 1878
}

Hitchcock, Edward, and others 1861

Hopkins, H. R. 1957

Jenkins 1938

King and Flawn 1953

McDonald 1941

Merrill 1901

Pearre and Heyl 1960

Rice and Gregory 1906

Ross and others 1955

Van Horn 1948

Virginia Geol. Survey 1928

White, W. S., and Jahns 1950

Mineral locality :

Barnes 1946

Beckwith 1939

Burfoot 1930, 1938

Chidester, Billings, and Cady 1951

Chidester, Engel, and Wright 1963

Chidester and Worthington 1962

Furcron and Teague 1947

Greaves-Walker and Riggs 1937

Hopkins, O. B. 1914

Keith, Arthur 1903

Luedke and others $\mathbf{1 9 5 9}$ 
Maps-Continued

Mineral locality-Continued

Midwest Research Institute 1946

Myer and Stewart $\mathbf{1 9 4 6}$

Osterwald, F. W., and others 1959

Pearre 1956, 1957

Pearre and Calkins 1957a, b

Perry, E. S. 1948

Pratt and Lewis $\mathbf{1 9 0 5}$

Valentine 1949

Van Horn 1948

Wright, L. A. 1957

Maryland :

Clark 1899

Pearre and Heyl 1961

Massachusetts :

Emerson 1917

Pearre 1956

Metamorphism :

Bain 1934, 1936

Benson 1918

Bowen 1940

Chawner 1934

Chidester 1959, 1962

Dresser 1934

Du Rietz 1935

Hess 1933a, b, 1935, 1955

Page 1951

Phillips and Hess 1936

Reed 1934

Wiik 1953

Wright, L. A. $\quad$ 1952, 1954, 1957

Mineral localities :

Alabama :

Jones 1939

McMurray and Bowles 1941

Reed 1950

Arkansas : Midwest Research Institute 1946

California :

Gay and Wright, I. A. 1954

Hall 1948

Hall and Mackevett 1958

Hietanen 1951

McDonald 1941

Page 1942, 1951

Tucker 1927

Tucker and Sampson $\mathbf{1 9 4 5}$

Wright, L. A. $1948,1949,1950,1952$, 1954,1957

Wright, L. A., Chesterman, and Norman 1954

Wright, L. A., Stewart, Gay, and Hazenbush 1953

Connecticut : Pearre 1957

Delaware: Pearre and Heyl 1960

Georgia :

Crickmay 1936

Furcron and Teague 1947

Hopkins, O. B. 1914

Hunter 1941

Hunter and Gildersleeve 1946

McCallie 1910

Idaho: Shannon 1926
Mineral localities-Continued

Maine :

Hurley and Thompson $\mathbf{1 9 5 0}$

Smith, G. D., and others 1907

Wing 1951

Wing and Dawson 1949

Maryland : Pearre and Heyl 1960

Massachusetts : Pearre 1956

Montana :

James 1946

Perry, E. S. 1948

U.S. Bureau of Mines 1944

Nevada: Page 1942

New Hampshire:

Hitchcock, C. H. 1878

Myers and Stewart 1946

Pearre and Calkins 1957b

New Jersey : Peck 1905

New Mexico :

Bailey 1949

Jicha 1954

New York :

Cushing and Newland 1925

Engel 1947, 1949b, 1962

Ladoo 1920

Luedke and others 1959

Nevius 1899

Newland 1921

Trainer 1940, 1941

Wade and Wandke 1923

Wasserman 1956

North Carolina :

Bryson 1932, 1937, 1938

Greaves-Walker and Riggs 1937

Hunter 1941

Hunter and Gildersleeve 1946

Keith, Arthur 1903, 1904, 1905, 1907

King and others 1958

Olson 1944

Pratt and George 1940

Pratt and Lewis 1950

Ralston 1944

Stuckey $1937,1942,1949,1950$

Stuckey and George 1940

Stuckey and others $\mathbf{1 9 4 7}$

Stuckey and steele 1953:

Van Horn 1948

Oklahoma : Midwest Research Institute 1946

Pennsylvania :

Montgomery 1955

Pearre and Heyl 1960

Peck 1905, 1911

Rhode Island: Pearre 1956

South Carolina: Sloane 1908

South Dakota : Dart 1959

Southeastern States :

Ralston 1944

Stuckey 1950

Texas:

Barnes 1940, 1946

Barnes and Mathis 1942

Barnes and others 1950

Dietrich and Lonsdale $\mathbf{1 9 5 8}$

Flawn 1958 
Mineral localities-Continued

Texas-Continued

King and Flawn 1953

Pence 1955

United States :

Chidester, Engel, and Wright 1968

Chidester and Worthington 1962

Diller 1909, 1911a, b, 1912, 1913, 1914,

$1916,1917,1919 a, b, 1920 a, b, 1921$

Ladoo 1923

Vermont :

Bain 1936, 1942

Billings and Chidester 1948a, b

Cady, Albee, and Chidester 1963

Chidester 1953, 1962

Chidester, Billings, and Cady 1951

Chidester, Stewart, and Morris 1952a

Chidester and Worthington 1962

Christman 1959

Gillson 1927

Hadley 1950

Hess 1933b

Hitchcock, Edward, and others

1861

Jacobs 1914, 1916, 1938, 1944

Ladoo 1919

Marsters 1904

Pearre and Calkins 1957a

Perry, E. L. 1929

Phillips and Hess 1936

Wigglesworth 1916

Zodac 1940

Virginia :

Bevan 1942

Brown, W. R. 1954

Burfoot 1930, 1932

Furcron 1935

Hess 1933a

Hopkins, H. R. 1957

McGill 1986

Ryan 1929

Smith, J. W. 1961

Washington :

Merten 1936

Valentine 1949

Wilson and Pask 1936a, b

Western States : Roff 1943

Wyoming :

Albanese 1950

Beckwith 1957

Osterwald, F. W., and Osterwald, D. B. 1952

Osterwald, F. W., and others 1959

Mineralogy :

Bailey 1949

Bassett 1959

Bates and Mink 1950

Bennington 1956

Bowen and Tuttle 1948, 1949

Brindley and Zussman 1957

Efremov 1953

Faust and Murata 1953

Fisher and Potter 1956

Foshag and Wherry 1922

Gordon 1921
Mineralogy-Continued
Gruner 1934
Heinricks and Jefferson 1938

Lamar 1944a

MeConnell 1954

Nagy 1953

Nagy and Bates 1952

Pask and Warner 1954

Roy, D. M., and Roy, Rustum 1954a, b

Searle and Grimshaw 1959

Stemple and Brindley 1960

Thurnauer and Rodriguez 1942

Vitaliano 1957

Wiik 1953

Wright, H. D. 1960

Zussman and others 1957

Mining and processing.

Mining :

Engel 1949a, b

Engel and Wright, L. A. 1960

Flawn 1958

Irving 1960

Ladoo 1919, 1920, 1923

Page 1942

Ryan 1929

Trainer 1940, 1941

Processing :

Clemmer and Cooke 1936

Dillender and Gower 1953

Engel 1949a, b

Engel and Wright, L. A. 1960

Frommer and Fine 1956

Gottlieb 1943

Gunzenhauser 1941

Hudspeth and others 1952

Irving 1960

Jacobs 1921

Ladoo 1923

Nevius 1899

Norman and others 1939

Ralston 1938

Thurnauer 1940

Montana :

James 1956

Heinrich 1947

Perry, E. S. 1948

Ross and others 1955

Swanson 1950

Nevada :

Page 1942

Vitaliano 1957

New Hampshire :

Billings 1956

Hitchcock, C. H. 1878

Myers and Stewart 1946

Pearre and Calkins 1957b

New Jersey :

Bayley 1941

Peck 1905

Zodac 1946

New Mexico :

Bailey 1949

Jicha 1954 
New York :

Areas :

Balmat-Edwards :

Brown, J. S., and Engel 1956

Engel 1962

Gouverneur :

Buddington 1926

Cushing and Newland 1925

Dake 1934

Engel 1947

Gilluly 1945

Norman and others 1939

General :

Engel 1949b

Ladoo 1920

Luedke and others 1959

Merrill 1901

Newland 1921

Miscellaneous :

Trainer 1940, 1941

Wade and Wandke 1928

Wasserman 1956

St. Lawrence County :

Nevins 1899a, 1899b

Smyth 1895

North Carolina :

Areas :

Murphy marble belt : Van Horn 1948 Spruce Pine : Olson 1944

Jackson County: Miller, Roswell, III 1953

General :

Bryson 1932, 1937, 1938

Greaves-Walker 1945

Greaves-Walker and Riggs 1937

Hart 1954

Hunter 1941

Keith, Arthur 1903

Moneymaker 1938

Murdock 1946

Pratt 1900

Stuckey 1937, 1942, 1949, 1958

Stuckey and others 1947

Stuckey and Steel 1953

Wake County :

Dillender and Gower 1953

Stuckey and George 1940

Western North Carolina :

Hunter and Gildersleeve 1946

Keith, Arthur 1904, 1905, 190 ?

King and others 1958

Pratt and Lewis 1905

Oklahoma : Midwest Research Institute 1946

Origin :

Bain 1934, 1942

Bates and Mink 1950

Benson 1918

Burfoot 1930, 1938

Chawner 1934

Chidester 1953, 1954, 1962

Chidester, Engel, and Wright 1968

Christman 1959

Dresser 1934

Du Rietz 1935
Origin-Continued

Engel 1949a, 1962

Engel and Wright, L. A. 1960

Furcron and Teague 1947

Gillson 1927

Hess 1933a, b, 1955

James 1946

Jicha 1954

Julien 1914

Montgomery 1955

Page 1951

Phillips and Hess 1936

Pratt and Lewis 1905

Read 1934

Skehan 1961

Smyth 1895

Taber 1916

Van Horn 1948

Wiik 1953

Wright, L. A. $1950 \mathrm{c}, 1952,1953,1954$, 1957

Pennsylvania :

Bayley 1941

Miller, B. L., and others 1939

Montgomery 1955

Pearre and Heyl 1961

Peck 1905, 1911

Stose and Jonas 1939

Production :

Statistics :

Bryson 1937

Diller 1909, 1911a, b, 1912, 1913, 1914, $1916,1917,1919 a, b, 1920 a, b, 1921$

Furcron and Teague 1947

Hopkins, O. B. 1914

Jacobs 1921

Ladoo 1923

Nevius 1899

Pearre and Heyl 1960

Teague 1950

U.S. Bureau of Mines $\quad 1932-62$

Van Horn 1948

Properties :

Chemical :

Lemmon and Watts 1943

Lipinski 1941

General :

Pask and Warner 1954

Roy, D. M., and Roy, Rustum 1954a, b

Searle and Grimshaw 1959

Industrial :

Carl 1945

Ferguson 1926

Gleason 1946

King 1935

Klinefelter, O'Meara, Smith, and Truesdell 1947

Kraner and McDowell 1925

Lamar 1952

Lemmon 1955

Mamykin and Permyakov 1931

Murdock 1946

Pence 1955 
Properties-Continued

Physical :

Bhushan and Roy, H. N. 1956

Carl 1945

Delaney 1940

Ewell and others 1935

Ferguson 1926

Fisher and Potter 1956

Grigorev 1937

Gruner 1934

Heinricks and Jefferson 1938

Lamar 1944

Moriyasu 1937

Selfridge 1936

Whittaker and Zussman $\mathbf{1 9 5 6}$

Related or associated minerals :

Clay minerals :

Hauser and LeBeau $\mathbf{1 9 4 6}$

Heinricks and Jefferson 1938

Miscellaneous :

Bassett 1959

Birch and Harvey 1935

Efremov 1953

Faust and Murata 1953

Gordon 1921

Hunter 1941

Miller, Roswell, III $\mathbf{1 9 5 3}$

Pyrophyllite :

Gower and Bell 1956

Gruner 1934

Hendricks and Jefferson 1938

Irving 1956

Johnson 1939

Pratt 1900

Stuckey 1942, 1950, 1958

Treischel 1957

U.S. Bureau of Mines 1932-60

Serpentine :

Bassett 1959

Bates and Mink 1950

Bowen and Tuttle 1948, 1949

Brindley 1954

Brindley and Zussman 1957

Chidester 1962

Deer and others 1962

Faust and Fahey 1962

Hess 1933b, 1935

Julien 1914

Keith, S. B., and Bain 1932

Montgomery 1955

Nagy 1953

Nagy and Bates 1952

Roy, D. M., and Roy, Rustum $\mathbf{1 9 5 4}$

Selfridge 1936

Taber 1916

Whittaker and Zussman $\mathbf{1 9 5 6}$

Zussman and others 1957

Reserves and resources.

General :

Blondel and Lasky 1956

Irving 1960

Ralston 1944

Stuckey 1950

Reserves: Lasky 1945
Reserves and resources-Continued

Resources:

Eastern U.S. :

Bayley 1941

Bevan 1942

Brown, W. R. 1954

Bryson 1932

Chidester 1953

Chidester, Billings, and Cady 1951

Chidester, stewart, and Morris 1952a, b

Engel 1962

Furcron and Teague 1947

Hopkins, O. B. 1914

Hurley and Thompson 1950

MeCallie 1910

McGill 1936

Newland 1921

Pearre and Heyl 1960

Reed 1950

Smith, J. W. 1961

Stose and Jonas 1939

Stuckey 1958

Stuckey and Steel 1953

Van Horn 1948

Western U.S. :

Barnes 1946, 1952

Barnes and Mathis 1942

Dietrich and Lonsdale 1958

Flawn 1958

Midwest Research Institute 1946

Page 1942, 1951

Perry, E. S. 1948

Tucker 1927

Tucker and Sampson 1945

Wright, L. A. 1952, 1953, 1954, 1957

Wright, L. A., Stewart, Gay, and

Hazenbush 1953

United States :

Chidester, Engel, and Wright 1963

Chidester and Worthington 1962

Lasky 1950

Rhode Island :

Emerson 1917

Pearre 1956

Quinn 1959

Serpentinization :

Bain 1934, 193.6

Benson 1918

Chawner 1934

Dresser 1934

Du Rietz 1935

Hess $1933 b, 1935,1955$

Montgomery 1955

Phillips and Hess 1936

Thomas 1951

Soapstone :

Economics: Johnson 1939

General :

Barnes 1946

Engel 1949a

Hughes 1932

Irving 1956

Ladoo 1923 
Soapstone-Continued

General-Continued

Mitchell 1944

Sampson 1922a, b, 1923

U.S. Bureau of Mines 1932-60

Wright, L. A. 1957

Location :

Miscellaneous States:

Barnes and Mathis 1942

Wilson and Pask 1936a, b

Southeastern U.S. :

Hopkins, H. R. 1957

Hopkins, O. B. 1914

Ryan 1929

Smith, J. W. 1961

Stuckey 1949, 1950

Origin :

Stuckey and George 1940

Hess 1933b, 1935

Wiik 1953

Properties : Delaney 1940

South Carolina: Sloane 1908

South Dakota : Dart 1959

Steatite :

California: Page 1951

Chemistry :

Chidester 1959

Lemmon and Watts 1943

Thurnauer and Rodriguez 1942

General :

Gunzenhauser 1941

Mitchell 1944

Properties :

Fisher and Potter 1956

Lamar 1944

White, J. S. 1944

Uses :

Gleason 1946

Hart 1954

Structure, talc deposits :

Bain 1942

Billings and Chidester 1948a

Brown, J. S., and Engel 1956

Brown, W. R. 1954

Clark 1899

Hall 1948

Stuckey 1942

White, W. S., and Jahns 1950

Tennessee :

Keith, Arthur 1904, 1905, 1907

King and others 1958

Texas :

Barnes 1940, 1946

Barnes and Mathis 1942

Barnes and others 1950

Darton and others 1937

Dietrich and Lonsdale 1958

Flawn $\mathbf{1 9 5 8}$

Frommer and Fine 1956

King and Flawn 1953

Moore 1947

Pence 1955

United States :

Avery and others 1958

Chidester, Engel, and Wright 1963
United States-Continued

Chidester and Worthington 1962

Diller 1909, 1911a, b, 1912, 1913, 1914, 1916, 1917, 1919a, b, 1920a, b, 1921

Engel 1949a

Engel and Wright, L. A. 1960

Gillson 1937

Irving 1960

U.S. Bureau of Mines 1932-62

Uses :

Ceramic :

American Ceramic Society 1922-62

Bhushan and Roy, H. N. 1956

Bryson 1938

Burchfiel 1935, 1936

Engle 1947

Greaves-Walker and Riggs 1937

Gunzenhauser 1941

Industrial Publications 1923-62

King 1935

Klinefelter, O'Meara, Smith, and Truesdell 1947

Kraner and McDowell $\mathbf{1 9 2 5}$

Lipinski 1941

Pask and Warner 1954

Pence 1955

Searle and Grimshaw 1959

Thurnauer 1940

Treischel 1957

General :

Barnes and others 1950

Engel 1949b

Gottlieb 1943

Ladoo 1923

Lamar 1944

Maynard and others 1923

Ralston 1944

Stuckey 1958

Stuckey and others 1947

Teague 1950

Wright, L. A., Chesterman, and Norman 1954

Insulation :

Gleason 1946

Klinefelter, Speil, and Gottlieb $\mathbf{1 9 4 5}$

Thurnauer 1950

Miscellaneous :

Betz 1933

Comefero and others 1954

Diller and others 1920

Hudspeth and others 1952

Jones 1939

King and Evans 1933

Lemmon 1955

Murdock 1946

Paint: Lamar 1952

Refractories:

Birch and Harvey 1935

Ferguson 1926

Goner and Bell 1956

Mamykin and Permyakov 1931

Steatite bodies :

Hart 1954

Lemmon and Watts $\mathbf{1 9 4 3}$ 




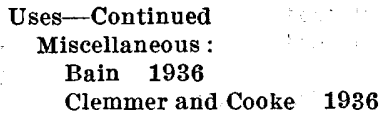

Osterwald, F. W., and others 1959 

